\title{
Evaluation of the Photodynamic Activity of Xanthene Dyes on Artemia salina described by Chemometric Approaches
}

\author{
DIOGO S. PELLOSI ${ }^{1}$, VAGNER R. BATISTELA ${ }^{1}$, VAGNER R. DE SOUZA ${ }^{1}$, \\ IEDA S. SCARMINIO ${ }^{2}$, WILKER CAETANO ${ }^{1}$ and NOBORU HIOKA ${ }^{1}$ \\ ${ }^{1}$ Departmento de Química, Universidade Estadual de Maringá, Av. Colombo, 5790, 87020-900 Maringá, PR, Brasil \\ ${ }^{2}$ Laboratório de Quimiometria em Ciências Naturais, Departamento de Química, Universidade Estadual de Londrina, \\ Rodovia Celso Garcia Cid, Pr 445, Km 380, Campus, 86051-980 Londrina, PR, Brasil
}

Manuscript received on February 20, 2012; accepted for publication on March 15, 2013

\begin{abstract}
The development of drugs for photodynamic therapy (PDT) is an important area of research due to their growing use in medical applications. Therefore, it is important to develop new bioassay methods for PDT photosensitizers that are inexpensive, easy to handle and highly sensitive to environmental conditions. Xanthene dyes (fluorescein, rose bengal B, erythrosine B and eosin Y) with LED light sources were investigated using Artemia salina as a bioindicator of photodynamic activity. In this study, three factors were investigated: (i) photosensitizers concentration, (ii) the LED irradiation time and (iii) the waiting time between the addition of the photosensitizers and the beginning of the irradiation. To analyze the photokilling of A. salina, it was employed a $2^{3}$ full factorial design. The death of A. salina was related to dye structure and the interaction between the irradiation time and the photosensitizers concentration. About $60 \%$ of crustaceans death was obtained using rose bengal $\mathrm{B}$, which presentes the highest quantum yield of singlet oxygen due to the number of iodide substituents in the xanthenes ring. The proposed bioassay using A. salina, xanthene dyes and LED irradiation was found suitable for quantitative PDT drug evaluation.
\end{abstract}

Key words: Artemia salina, factorial design, photodynamic therapy, bioassay, xanthenes.

\section{INTRODUCTION}

Photodynamic Therapy (PDT) has been used in the treatment of diseases characterized by the abnormal growth of tissues, such as rheumatoid arthritis, vitiligo, pathological myopia, macular degeneration, and retinal microbial infestations (Allison et al. 2004, Paszko et al. 2011, Hansch et al. 2008, Simplicio et al. 2002, Taub 2007, Peloi et al. 2008). However, the most outstanding application of PDT is in the fight against cancer (Dolmans et al. 2003, Tardivo et al. 2006).

Correspondence to: Noboru Hioka

E-mail:nhioka@uem.br
PDT is based on the interaction of a photosensitizing drug (PS) with visible light irradiation of appropriate intensity and wavelength to irradiate the affected area (Castano et al. 2004, Handerson and Dougherty 1992). The photo-activation of the PS generates cytotoxic species that promote apoptosis or necrosis of the diseased tissue in situ (MacDonald and Dougherty 2001, Machado 2000). There are two types of photochemical reactions that generate these reactive species. The type-1 mechanism generates Reactive Oxygen Species (ROS) through an electron transfer reaction from 
the excited PS, while the type-2 mechanism is related to the energy transfer reaction between the excited PS in triplet state and oxygen, which results in singlet oxygen $\left({ }^{1} \mathrm{O}_{2}\right)$. Both mechanisms cause significant damage to cell structures.

One major limitation of PDT is the high cost of its usual light source, LASER. Even with the less expensive diode-based LASER, in developing countries the cost of clinical applications is still restrictive. An alternative source of light for PDT is the light emitting diode (LED), which is far more inexpensive and emits light covering nearly all the visible spectrum. LED has lower irradiation potency than LASER, however it is more economical and its versatility allows for broader PDT application. Despite its low light intensity, LED can be used in the treatment of superficial skin and eye diseases (Mang 2004, Goldberg and Russell 2006, Ibbotson 2010, Brancaleon and Moseley 2002).

Besides the high cost of its light source, PDT is also limited by the high prices of the drugs used. Therefore, there are extensive studies for new photosensitizers that to combine high PDT efficiency, minor side effects, and low cost. Some xanthene dyes, such as rose bengal $\mathrm{B}(\mathrm{RBB})$, have been proposed as candidates for PDT. RBB is a derivative known for its high ability to generate singlet oxygen (Gandin et al. 1983). Besides RBB, other xanthene derivatives, such as erythrosine (ERI) and eosin Y (EOS), also exhibit high quantum yields of singlet oxygen (Gandin et al. 1983) making them candidates for PDT. Some studies already show photodynamic applications with these PS with great success (Shen et al. 2000, Wood et al. 2006). These three xanthene compounds generate high amounts of ${ }^{1} \mathrm{O}_{2}$, unlike fluorescein (FSC), a xanthene dye that is largely employed as a probe in clinical-medical applications due to its elevated fluorescence (structures in Figure 1).

However, the high quantum yields of singlet oxygen produced by the type- 2 mechanism are not the only determining factors for the effectiveness of a PS in PDT. Other factors include: (i) the complex

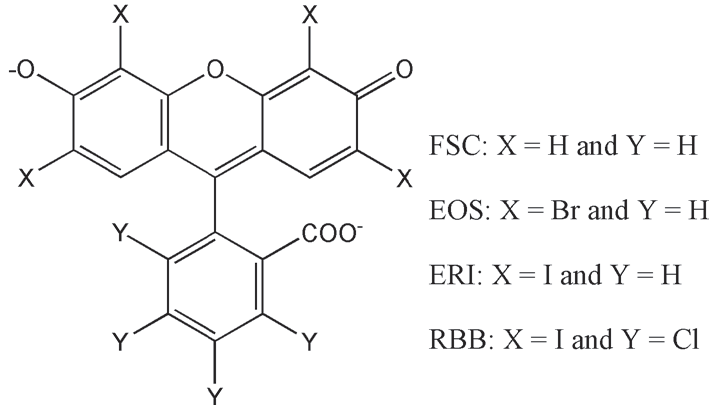

Figure 1 - Xanthene dyes structures.

cellular interactions, which vary according to the studied organism, (ii) the drug delivery efficiency, (iii) the appropriateness of physical-chemical properties, such as photostability, high light absorption at adequate wavelengths, etc, (iv) the potential side effects for patients, and $(v)$ the possibility of the type-1 mechanism via ROS formation.

In the present work, a simple preliminary evaluation of photodynamic activity in vivo is proposed using brine shrimp, Artemia salina. These tiny crustaceans are inexpensive, easy to handle, and highly sensitive to environmental conditions, making them useful for research of bioactive agents and good bioindicators of wastewatertoxicity(Meyeretal.1982, Rodrigues et al. 2007, Kinghorn et al. 1977, Boroski et al. 2008). Since the death of this microcrustacean results from the action of specific substances, the death rate can be correlated to the photodynamic activity of the PS. This work describes the evaluation of the photodynamic activity of xanthene derivatives against the microcrustacean Artemia salina. The effects of three important factors to the photo-killing process of this organism were investigated: (i) PS concentration, (ii) the LED irradiation time, and (iii) the waiting time between the addition of the PS and the beginning of the irradiation. For the analysis, $2^{3}$ full factorial design was employed as a statistical tool based on two-level chemometry to evaluate the PDT activity against $A$. salina. This strategy identified the individual influences and parameter interactions of the PS factors in biological media (Mason et al. 2003, Neto et al. 2010). 


\section{MATERIALS AND METHODS}

Aqueous saline ( $\left.1 \mathrm{~L}, \mathrm{NaCl}, 0.1 \mathrm{~mol} \mathrm{~L}^{-1}\right)$ was prepared in a buffered medium at $\mathrm{pH} 7.25$ $\left(\mathrm{Na}_{2} \mathrm{HPO}_{4}, 7.5 \times 10^{-3} \mathrm{~mol} \mathrm{~L}{ }^{-1}\right)$ and transferred to a rectangular vessel consisting of two interrelated parts (an irradiated section and another kept in the dark). The microcrustacean eggs were placed in the dark section. The irradiated section had one $60 \mathrm{~W}$ fluorescent lamp, which attracted newly hatched animals (Figure 2A). After 48 h, 20 mature animals were transferred to test tubes and maintained at approximately $24{ }^{\circ} \mathrm{C}$. Stock solutions of the dyes were added at the desired concentration and then filled up to $3.0 \mathrm{~mL}$ by adding the previously prepared $\mathrm{NaCl}$ solution. FSC (Carlo Erba), EOS (Reagen), ERI (Vetec), and RBB (Nuclear) were used without further purification.

A green LED (Sun Co.) was utilized as light source and its emission spectrum was obtained using a Fluorog2 Spex spectrofluorimeter, model 168. The individual potency of each LED was measured using a Handheld Power Meter (Edmund Optics Inc.). The LED source was constructed using six LED units. The samples were wrapped with aluminum foil and the top side was irradiated with the LED (Figure 2B). After irradiation, the live and dead animals were counted.

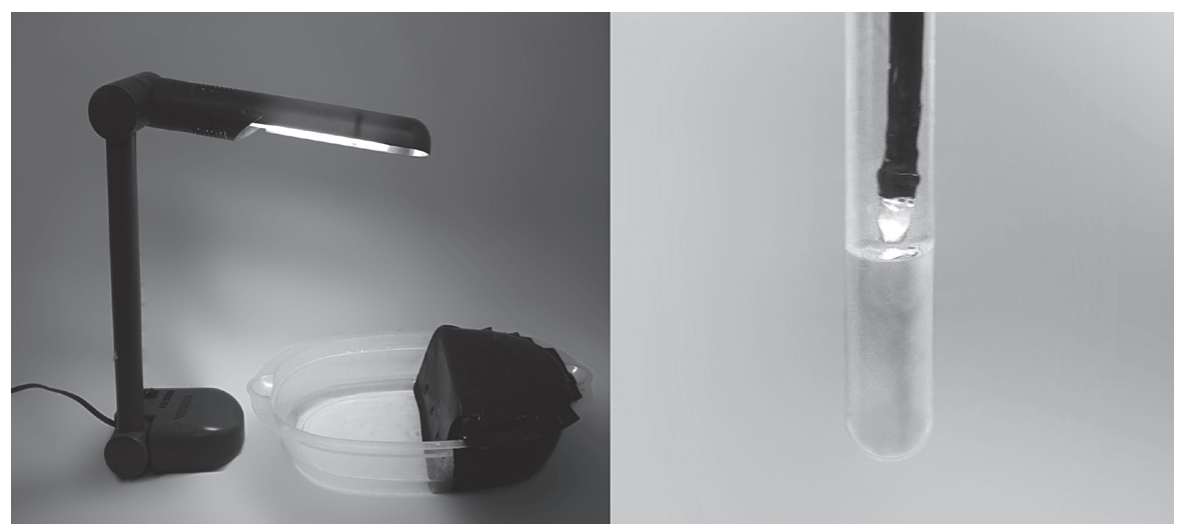

Figure 2 - (A) Container used for hatching brine shrimp; (B) Tube containing A. salina microcrustaceans and RBB aqueous solution irradiated with LED.

The death rate of $A$. salina was used as a factorial design response factor. The factors relevant to photodynamic effects were assessed using a $2^{3}$ full factorial design at two levels (low - and high + ) to evaluate the photosensitizer concentration [PS]), the LED irradiation time ( $t_{i}$, in hours), and the waiting time between the addition of the PS and the beginning of the irradiation ( $t_{e}$ in hours). The experimental design and statistical analysis were performed using the software Design Expert ${ }^{\mathrm{TM}}$ version 7.1.3 (Stat Ease Inc 2011). The factors and the investigated high and low level conditions are presented in Table I. All percentages were corrected for the natural death rate of the animals in the samples not subject to either irradiation or dye. All trials were carried out in triplicate and the data were reported as means $\pm \mathrm{SD}$ (standard deviation).

TABLE I

Investigated photodynamic activity factors with the levels used in $A$. salina bioassays.

\begin{tabular}{ccc}
\hline Factors & Low level (-) & High level $(+)$ \\
\hline 1: $[\mathrm{PS}]\left(\right.$ mmol. $\left.^{-1}\right)$ & 25 & 250 \\
2: irradiation time, $\mathrm{t}_{\mathrm{i}}(\mathrm{h})$ & 1 & 3 \\
3: waiting time, $\mathrm{t}_{\mathrm{e}}(\mathrm{h})$ & 0 & 1 \\
\hline
\end{tabular}

[PS] : photosensitizer concentration. 


\section{RESULTS AND DISCUSSION}

For all bioassays the samples were kept in a buffered aqueous solution at $\mathrm{pH} 7.25$, the natural $\mathrm{pH}$ of living organisms. At this $\mathrm{pH}, \mathrm{FSC}$ is mostly in the dianion protolytic form (91\%), with a calculated pKa of 6.2 (Batistela et al. 2010, Sjöback et al. 1995), which corresponds to the phenolic group. All other PS at pH 7.25 were found in the dianionic form due to an approximate $\mathrm{pKa}$ of 4 (Batistela et al. 2011). The charges of these protolytic species and the small PS concentration employed ensured that all PS molecules were monomers, instead of self-aggregates. The selfaggregation of the PS in water is a problem in PDT that must be avoided (Valdes-Aguilera and Neckers 1989) as it drastically reduces singlet oxygen formation (Machado 2000).

\section{ANALYSIS OF THE LED SYSTEMS}

The chosen LED has a maximum light emission at $518 \mathrm{~nm}$, which is in the range of absorption of the xanthene dyes investigated. The measured potency of each LED unit is $2.11 \mathrm{~mW}$. The replacement of LASER for LED, in addition to its economic advantages, allowed for a light source that covered almost all the visible light spectrum, despite its low irradiation potency. In the present study, the LED source was very convenient, allowing for six experiments to be conducted simultaneously. Another advantage of LED over LASER is that its use minimizes undesirable side reactions, such as photobleaching that reduces the required PS concentration, consequently diminishing the photodynamic activity (Bonnett and Martínez 2001, Mang et al. 2008).

\section{CHEMOMETRIC ANALYSIS}

Table II displays the experimental design with the death rates of the microcrustaceans for each PS irradiated with LED. The three factors, $[\mathrm{PS}], \mathrm{t}_{\mathrm{i}}$, and $t_{e}$ were chosen according to the dye concentration, the duration of LED irradiation, and the time necessary for in situ accumulation of appropriate amounts of PS for irradiation.

TABLE II

Average percentage of death for $A$. salina with the photosensitizers irradiated with LED.

\begin{tabular}{|c|c|c|c|c|c|c|c|}
\hline Exp. & [PS] & $\mathbf{t}_{\mathrm{i}}$ & $\mathbf{t}_{\mathrm{e}}$ & FSC & EOS & ERI & RBB \\
\hline 1 & - & - & - & $11.72 \pm 0.63$ & $24.53 \pm 0.94$ & $26.36 \pm 0.95$ & $30.39 \pm 1.69$ \\
\hline 2 & + & - & - & $15.14 \pm 2.50$ & $39.57 \pm 0.66$ & $35.19 \pm 0.99$ & $38.13 \pm 1.03$ \\
\hline 3 & - & + & - & $8.79 \pm 1.61$ & $36.25 \pm 0.59$ & $36.05 \pm 1.60$ & $41.11 \pm 1.21$ \\
\hline 4 & + & + & - & $17.96 \pm 0.84$ & $49.65 \pm 1.06$ & $52.23 \pm 1.77$ & $57.06 \pm 1.21$ \\
\hline 5 & - & - & + & $7.76 \pm 1.69$ & $26.54 \pm 0.21$ & $26.73 \pm 1.09$ & $28.79 \pm 0.85$ \\
\hline 6 & + & - & + & $15.95 \pm 1.97$ & $33.07 \pm 1.49$ & $36.34 \pm 1.69$ & $37.27 \pm 1.48$ \\
\hline 7 & - & + & + & $8.15 \pm 0.54$ & $36.62 \pm 0.32$ & $35.89 \pm 1.42$ & $40.29 \pm 1.04$ \\
\hline 8 & + & + & + & $18.20 \pm 1.81$ & $51.84 \pm 1.09$ & $56.03 \pm 1.24$ & $61.23 \pm 0.53$ \\
\hline
\end{tabular}

* The symbols (-) and (+) represent the low and high level of each factor respectively.

The data in Table II show that the halogenated dyes (EOS, ERI and RBB) are much more phototoxic than FSC in all experiments performed on the microcrustaceans. The actual influence of each factor on animal death was evaluated by the chemometric treatment.

The two-level analysis of the factorial design begins with the calculation of the main effects of 
all factors and the interactions between them. All effect values (E) were calculated using Equation 1 with the results from Table II:

$$
\bar{y}_{+}-\bar{y}_{-}
$$

In this equation, $\bar{y}_{+}$and $\bar{y}_{-}$represent the average results obtained with high $(+)$ and low (-) levels, respectively (Neto et al. 2010). The + and - signs used in this equation are given in the appropriate column of Table II for each factor. The signs of the interaction effects were calculated by multiplying the sign columns for the factors involved in the respective interaction. Table III shows the factors' intensities and the parameters of interactions for the death rate in the bioassays, calculated using the chemometric tools. The quantum yields of ${ }^{1} \mathrm{O}_{2}$ generation for all PS investigated are also included in Table III.

TABLE III

Effects calculated for the photodynamic activity with the photosensitizers based on $2^{3}$ factorial design. Some high values are highlighted.

\begin{tabular}{|c|c|c|c|c|}
\hline Exp. Factors* $^{*}$ & FSC (0.03) & EOS (0.57) & ERI (0.63) & RBB (0.75) \\
\hline Mean & $12.96( \pm 0.27)$ & $37.26( \pm 0.17)$ & $\mathbf{3 7 . 6 9}( \pm 0.12)$ & $41.78( \pm 0.29)$ \\
\hline (1) $[\mathrm{PS}]$ & $7.71( \pm 0.35)$ & $\mathbf{1 2 . 5 5}( \pm 0.35)$ & $13.20( \pm 0.24)$ & $13.28( \pm 0.58)$ \\
\hline (2) $t_{i}$ & $0.63( \pm 0.35)$ & $12.66( \pm 0.35)$ & $\mathbf{1 3 . 0 7}( \pm 0.24)$ & $16.28( \pm 0.58)$ \\
\hline (3) $t_{e}$ & $-0.83( \pm 0.35)$ & $-0.48( \pm 0.35)$ & $0.47( \pm 0.24)$ & $0.22( \pm 0.58)$ \\
\hline$[\mathbf{P S}] \times \mathbf{t}_{\mathrm{i}}$ & $1.90( \pm 0.35)$ & $1.76( \pm 0.35$ & $3.98( \pm 0.24)$ & $\mathbf{5 . 1 7}( \pm 0.58)$ \\
\hline$[\mathbf{P S}] \times \mathbf{t}_{\mathrm{e}}$ & $1.41( \pm 0.35)$ & $-1.67( \pm 0.35)$ & $0.70( \pm 0.24)$ & $1.43( \pm 0.58)$ \\
\hline $\mathbf{t}_{\mathrm{i}} \times \mathbf{t}_{\mathrm{e}}$ & $0.69( \pm 0.35)$ & $1.76( \pm 0.35)$ & $-0.29( \pm 0.24)$ & $1.45( \pm 0.58)$ \\
\hline$[\mathbf{P S}] \times \mathbf{t}_{\mathrm{i}} \times \mathbf{t}_{\mathrm{e}}$ & $-0.97( \pm 0.35)$ & $\mathbf{2 . 5 8}( \pm 0.35)$ & $0.31( \pm 0.24)$ & $1.06( \pm 0.58)$ \\
\hline
\end{tabular}

* In parenthesis are presented the singlet oxygen quantum yield formation for each dye in water solution (Gandin et al. 1983).

The low photoactivity of FSC and the high photoactivity of EOS, ERI and RBB (Tables II and III) seem to be related to singlet oxygen yields as a result of the type- 2 mechanism. Instead of generating singlet oxygen, FSC is highly fluorescent, when compared to the other xanthenes investigated, which have poor fluorescence yields and high singlet oxygen quantum yields (values in Table III). These results indicate that the type- 1 photoreaction mechanism by electron transfer is not relevant for the photodynamic activity of xanthene dyes. The presence of halogens causes high ${ }^{1} \mathrm{O}_{2}$ formation by the excited state of EOS, ERI and RBB.

These photosensitizers have several heavy halogen atoms; their high electron densities permit the inter-system crossing of the excited PS to the triplet state ( ${ }^{1} \mathrm{PS} \rightarrow{ }^{3} \mathrm{PS}$ ). The large formation of ${ }^{3} \mathrm{PS}$ favors the energy transfer reaction to molecular oxygen $\left({ }^{3} \mathrm{O}_{2}\right)$ leading to formation of ${ }^{1} \mathrm{O}_{2}$. These results are supported by most authors who indicate singlet oxygen as the main PDT mechanism (Weishaupt et al. 1976), i.e. type-2 mechanism. This species is highly reactivity and has a short lifetime in biological tissues (Foote and Clennan 1995).

The irradiated FSC system produced the lowest death rate in the crustaceans, an average of $12.96 \%$ (Table III). It was observed that only the global average and the [PS] were significant for FSC at $95 \%$ confidence. The results show that by increasing the FSC from $25 \mu \mathrm{mol} . \mathrm{L}^{-1}$ to 250 
$\mu$ mol. $L^{-1}$ the percentage of animal death increases by an average of $7.7 \%$. This value corresponds to the lethality of the compound itself (sample in the dark with FSC), demonstrating FSC's natural toxicity against brine shrimp. However, it was also observed in Table III that the average effect of dye concentration for EOS, ERI and RBB had nearly two-fold intensity when compared to that of FSC. For all xanthene systems, animal death increased as the [PS] concentration increased.

The factor $t_{e}$ by itself did not seem to be relevant. However, the photodynamic mechanism of EOS is more complex than that of any of the other photosensitizers due to the interaction effect between the three factors studied. The main effects of factor $t_{e}$ were not significant at 95\% confidence for any of the dyes, yet it exhibited interaction effects with the other two factors, indicating that the waiting time for the addition of the PS into the microcrustaceans cannot be neglected. Thus, this effect by itself has no direct involvement with the photodynamic activity, but the data suggest that there are minor effects when combined with the other factors.

The calculated data in Table III also show that the irradiation time $\left(\mathrm{t}_{\mathrm{i}}\right)$ was significant for the three halogenated xanthenes. The time 1 hour showed $30 \%$ of death and 3 hours about 60 $\%$ of death for RBB. The interval of 1 hour of irradiation was not sufficient for a significative death of microcrustaceans, but the interval used is good enough for statistical evaluation. Both [PS] and $t_{i}$ showed the same profile as singlet oxygen was yielded, i.e., the death rates increased as these factors increased. The data also shows that RBB, which had the highest quantum yield of ${ }^{1} \mathrm{O}_{2}$, was the photosensitizer with the highest intensity of factors $t_{i}$ and [PS]. These high values of $t_{i}$ for EOS, ERI and $\mathrm{RBB}$ evidenced that increasing the irradiation time increases the death rate of $A$. salina. Thus, derivatives with higher photodynamic action must have greater [PS] and $t_{i}$ effects, as well as higher interactions effects for both [PS] and $\mathrm{t}_{\mathrm{i}}$.
In analysis of variance (ANOVA), the mean square represents the variance of experimental data that is explained by the model (Mason et al. 2003, Neto et al. 2010). The ANOVA, using the interaction parameter $[\mathrm{PS}] \times \mathrm{t}_{\mathrm{i}}$, exhibits the same profile as [PS] and $t_{i}$ individually for the percentage of death according to the PS, as shown in Table IV. The photosensitizers with the highest photodynamic activity are those with the highest means square for the term $[P S] \times t_{i}$, which in this study are ERI and RBB. This intense interaction agrees with the values of $\Phi^{1} \mathrm{O}_{2}$. Therefore, the photodynamic efficiency against A. salina depends on the generation of singlet oxygen by the interaction of light with PS.

TABLE IV

Analysis of the obtained ANOVA mean square.

\begin{tabular}{cccc}
\hline PS & $\begin{array}{c}{[\mathbf{P S}] \text { Mean }} \\
\text { square }\end{array}$ & $\begin{array}{c}\mathbf{t}_{\mathbf{i}} \text { Mean } \\
\text { Square }\end{array}$ & $\begin{array}{c}{[\mathbf{P S}] \times \mathbf{t}_{\mathbf{i}} \text { Mean }} \\
\text { Square }\end{array}$ \\
\hline FSC & 118.81 & 0.80 & 7.27 \\
EOS & 314.88 & 320.68 & 6.21 \\
ERI & 348.61 & 341.78 & 31.72 \\
RBB & 352.58 & 529.91 & 53.41 \\
\hline
\end{tabular}

For the four dyes studied, a mathematical model was proposed to describe the photodynamic behavior represented by Equations 2, 3, 4, and 5 .

$\%($ FSC $)=12.96+3.85 \times$ [PS] $\mathrm{R}^{2}=0.9379$ Eq. (2)

$\%($ EOS $)=37.26+6.27 \times[P S]+6.33 \times \mathrm{t}_{\mathrm{i}} \mathrm{R}^{2}=$ 0.9616 Eq. (3)

$\%($ ERI $)=37.69+6.60 \times[P S]+6.54 \times t_{i}+1.99 x$ $[\mathrm{PS}] \mathrm{x}$ ti $\mathrm{R}^{2}=0.9976$ Eq. (3)

$\%(\mathrm{RBB})=41.78+6.64 \mathrm{x}[\mathrm{PS}]+8.14 \times \mathrm{t}_{\mathrm{i}}+2.58 \mathrm{x}$ [PS] x ti $\mathrm{R}^{2}=0.9887$ Eq. (4)

The linear terms in each equation are the averages of each system and their coefficients indicate the intensity of the contribution of each factor to the photodynamic response. The four equations presented satisfactory adjustment to the experimental data, as demonstrated by the coefficient of determination $\mathrm{R}^{2}$. The residues between experimental data and the 
values predicted by the equation obtained by ANOVA were random, which indicates that the mathematical models are satisfactory.

\section{CONCLUSIONS}

The main effects for the factors [PS] and $t_{i}$ were significant at $95 \%$ confidence for the four dyes. The death of $A$. salina is related to the structure of the photosensitizers through the interaction between the irradiation time and the photosensitizer concentration that yields singlet oxygen. About $60 \%$ of animal death was obtained using RBB, which is the photosensitizer that presented the highest quantum yields of singlet oxygen due to the number of iodide substituents in its rings. The factorial design based on chemometry allowed us to determine the main factors related to the photodynamic action of xanthene photosensitizers with very similar structures. The proposed bioassay using A. salina, xanthene dyes, and LED was found suitable for PDT drug evaluation.

\section{ACKNOWLEDGMENTS}

This research was supported by grants from the Brazilian agencies Conselho Nacional de Desenvolvimento Científico e Tecnológico (CNPq), Fundação Araucária/SETI-Paraná and Coordenação de Aperfeiçoamento do Pessoal do Nível Superior (CAPES). The authors thank Laerte J. da Silva for the English language revision.

\section{RESUMO}

O desenvolvimento de fármacos para terapia fotodinâmica (TFD) é uma importante área de pesquisa devido ao seu crescente uso em aplicações médicas. Portanto, é importante desenvolver novos métodos de bioensaios para TFD fotossensibilizadores que sejam de baixo custo, de fácil execução e altamente sensíveis às condições do meio. Corantes xantênicos (fluoresceína, rosa de bengala $\mathrm{B}$, eritrosina $\mathrm{B}$ e eosina $\mathrm{Y}$ ) iluminados com luz LED foram investigados usando Artêmia salina como bioindicador da atividade fotodinâmica. Neste estudo, três fatores foram investigados (i) concentração do fotossensibilizador; (ii) o tempo de irradiação LED e (iii) o tempo de espera entre a adição do fotossensibilizador e o início da irradiação. Para analisar a foto-mortandade da A. salina foi aplicado o planejamento fatorial $2^{3}$ completo. A morte da A. salina foi relacionada à estrutura do corante e à interação entre o tempo de irradiação e a concentração do fotossensibilizador. Cerca de $60 \%$ da morte do crustáceo foi obtida usando rosa de bengala B, que apresenta o maior rendimento quântico de oxigênio singlete devido aos átomos de iodo substituintes no anel xantênico. O bioensaio proposto usando A. salina, corantes xantenos e irradiação LED foi apropriado para a avaliação quantitativa de fármacos para TFD.

Palavras-chave: Artêmia salina, planejamento fatorial, terapia fotodinâmica, bioensaio, xantenos.

\section{REFERENCES}

Allison RR, Downie GH, Cuenca R, Hu X, Childs CJH AND SibATA CH. 2004. Photosensitizers in clinical PDT. Photodiagn Photodyn Ther 1: 27-42.

BATISTELA VR, CEDRAN JC, OLIVEIRA HPM, SCARMINIO IS, UENO LT, MACHADO AEH AND HIOKA N. 2010. Protolytic fluorescein species evaluated using chemometry and DFT studies. Dyes Pigm 86: 15-24.

Batistela VR, Pellosi DS, Souza FD, Costa WF, Santin SMO, SOUza VR, CAETANO W, Oliveira HPM, SCARMINIO IS AND HIOKA N. 2011. pKa determinations of xanthene derivates in aqueous solutions by multivariate analysis applied to UV-Vis spectrophotometric data. Spectrochim Acta A 79: 889-897.

BonnetT R AND MARTínez G. 2001. Photobleaching of photosensitizers used in photodynamic therapy. Tetrahedron 57(47): 9513-9547.

Boroski M, Rodrigues A, Garcia J, Gerola A, Nozaki J AND HIOKA N. 2008. The effect of operational parameters on electrocoagulation-flotation process followed by photocatalysis applied to the decontaminationof water effluents from cellulose and paper factories. J Hazard Mater 160(1): 135-141.

BRANCALEON L AND Moseley H. 2002. Laser and Non-laser Light Sources for Photodynamic Therapy. Laser Med Science 17(3): 173-182.

Castano AP, Demidova TN AND Hamblin MR. 2004. Mechanisms in photodynamic therapy: part one photosensitizers, photochemistry and cellular localization. Photodiagn Photodyn Ther 1: 279-293.

DOLMANS DEJGJ, FUKUMURA D AND JAIN RK. 2003. Photodynamic therapy for cancer. Nat Rev Cancer 3: 380-387. 
Foote CS AND ClenNAN EL. 1995. Active Oxygen in Chemistry. Vol 2. London: Chapman \& Hall, p. 105-140.

GANDIN E, LION Y AND VAN DER VORST A. 1983. Quantum yield of singlet oxygen production by xanthene derivatives. Photochem Photobiol 37(3): 271-278.

GoldBerg DJ AND Russell BA. 2006. Combination blue $(415 \mathrm{~nm})$ and red $(633 \mathrm{~nm})$ LED phototherapy in the treatment of mild to severe acne vulgaris. J Cosmet Laser Ther 8: 71-75.

HANDERSON B AND DOUGHERTY T. 1992. How does Photodynamic Therapy Work? J Photochem Photobiol 55(1): 145-157.

Hansch A, Frey O, Gaida M, Susanna G, Boettcher J, BRAUER R AND KAISER WA. 2008. Photodynamic treatment as a novel approach in therapy of arthritic joints. Lasers Surg Med 40: 265-272.

IBBOTSON SH. 2010. An overview of topical photodynamic therapy in dermatology. Photodiagn Photodyn Ther 7: 16-23.

KINGHORN AD, HARJES KK AND DOORENBOS NJ. 1977. Screening procedure for phorbol esters using brine shrimp (Artemia salina) larvae. J Pharm Sci 66(9): 1362-1363.

MACDONALD IL AND DougherTy TJ. 2001. Basic principles of photodynamic therapy. J Porph Phthal 5(2): 105-129.

MachAdo AEH. 2000. Terapia Fotodinâmica: Princípios, potencial de aplicação e perspectivas. Quím Nova 23(2): 237-243.

MANG TS. 2004. Lasers and light sources for PDT: past, present and future. Photodiagn Photodyn Ther 1(1): 43-48.

Mang TS, Dougherty TJ, PotTer WR, Boyle DG, SOMER S AND MOAN J. 2008. Photobleaching of porphyrins used in photodynamic therapy and applications for therapy. Photochem Photobiol 45(4): 501-506.

Mason RL, Gunst RF AND Hess JL. 2003. Statistical Design and Analysis of Experiments. $2^{\text {nd }}$ ed., New Jersey: Wiley Interscience, $746 \mathrm{p}$.

Meyer BN, Ferrigini NR, Putnan JE, JACobsel LB, NiCHOLS DE AND NCLAUGHLIN JL. 1982. Brine shrimp: a convenient general bioassay for active plant constituents. Planta Med 45: 31-34.

Neto BB, SCARMinio IS AND BRUnS RE. 2010. Como fazer experimentos. $4^{\text {th }}$ ed., São Paulo: Bookman, 414 p.
Paszko E, Ehrhardt C, Senge MO, Kelleher DP AND REYNOLDS JV. 2011. Nanodrug applications in photodynamic therapy. Photodiagn Photodyn Ther 8: 14-29.

Peloi LS, Hioka N, SoAREs RRS, SOUZA VR, Biondo CE AND KIMURA E. 2008. Photodynamic effect of light-emitting diode light on cell growth inhibition induced by methylene blue. J Biosci Bioeng 33(2): 231-237.

Rodrigues AC, BOROSKI M, SHIMADA NS, GARCIA JC, NOZAKI J AND HIOKA N. 2007. Treatment of paper pulp and paper mill wastewater by coagulation-flocculation followed by heterogeneous photocatalysis. J Photochem Photobiol A 194: 1-10.

SHEN H, SpIKes JD, SMITH CJ AND KOPEČEK J. 2000 Photodynamic cross-linking of proteins - IV. Nature of the His-His bond(s) formed in the rose bengal-photosensitized cross-linking of N-benzoyl-L-histidine. J Photochem Photobiol A 130: 1-6.

Simplicio FI, MaiOnCHI F AND HiOKA N. 2002. Terapia fotodinâmica: aspectos farmacológicos, aplicações e avanços recentes no desenvolvimento de medicamentos. Quím Nova 25(5): 801-807.

SJÖBACK R, NYGREN J AND KUBISTA M. 1995. Absorption and fluorescence properties of fluorescein. Spectrochim Acta A 51: L7-L21.

Stat EASE INC. 2011. http://www.statease.com. Accessed in $01 / 12 / 2011$

TARDIVO JP, DEL GIGLIO A, PASCHOAL LH AND BAPTISTA MS. 2006. New photodynamic therapy protocol to treat AIDSrelated Kaposi's sarcoma. Photomed Laser Surg 24(4): 528-531.

TAUB AF. 2007. Photodynamic therapy: other uses. Dermatol Clin 25: 101-109.

VALDES-AGUILERA O AND NECKERS DC. 1989. Aggregation phenomena in xanthene dyes. Acc Chem Res 22(5): 171-177.

WeISHAUPT KR, GOMER CJ AND DOUGHERTY TJ. 1976. Identification of singlet oxygen as the cytotoxic agent in photo-inactivation of a murine tumor. Cancer Res 36 : 2326-2329.

Wood S, Metcalf D, Devine D and Robinson C. 2006 Erythrosine is a potential photosensitizer for the photodynamic therapy of oral plaque biofilms. J Antimicrob Chemother 57: 680-684. 